\title{
Narratives of translation and belonging in multilingual performance: The case study of $20 / 20$
}

\section{Jozefina Komporaly}

De Montfort University, UK

jokom2014@gmail.com

This article investigates ways in which theatre and performance have the potential to revisit and re-interpret ideological narratives. Drawing on the politics of transnational performance-making processes, it examines how multilingual theatre can contribute to the production of subjective and collective identities, and help articulate ideas and perceptions of belonging. With reference to 20/20 - a piece of documentary-style theatre about a major inter-ethnic conflict that took place in 1990 in a bilingual city in Romania - this case study maps out arguments for utilizing multilingualism on stage, and engages with the ethics of representation in the process of multilingual transfer. Billed as 'multi-ethnic and multilingual', the production embraces an agenda that goes beyond the examination of an isolated local conflict and makes the point that both theatre-making and theatre-going are experiences that strongly interact with narratives of cultural identity and hybridization. Thus, the representation of belonging or not belonging is tied in with questions of agency, and the right of individuals to affirm and indeed interrogate their hereditary links to a community.

\section{Introduction}

Multilingualism and translation tend not to be routinely examined together in academic discourse, in spite of both generating heated discussions in their own right. At a quick glance, it would appear that they deal with complementary phenomena: the former implies the simultaneous presence of at least two languages, while the latter suggests the substitution of one language with another. As a general rule, translations are not intended to be read alongside their originals; they are commissioned for and utilized in practice for the benefit of monolingual readers, "thus restricting bilingual competence to the translators themselves" (Grutman, 2011, p. 182). This paper aims to investigate situations where bilingual, and indeed multilingual, competence is not the exclusive domain of translators, and was prompted by my reflections on the circumstances of communication in an ethnically and linguistically heterogenous environment. Although many parts of the world could be described as multilingual, and indeed multiethnic, communication is more often than not filtered through a clearly identifiable dominant language. 
The consequences of such practices are widely documented and do not concern this case study. Its scope, rather, is to hone in on circumstances where the dominance of a particular category over others is in negotiation, and I claim that theatre and performance are powerful instruments in revisiting, reassessing and re-interpreting ideological narratives. Examining how multilingual theatre productions can contribute to the making of subjective and collective identities, my aim is to analyze the juxtaposition - and dialogue - of multiple languages in the context of a single theatre performance and argue that they can help articulate ideas and perceptions of belonging.

Drawing on the detailed examination of $20 / 20$ by Gianina Cărbunariu (2009), a piece of documentary-style theatre about a major inter-ethnic conflict that took place in 1990 in the bilingual Romanian/Hungarian city of Tîrgu Mureş/Marosvásárhely in Romania the article documents the utilization of multilingualism on stage, and engages with the ethics of representation in the process of multilingual transfer. Carefully labelled as multi-ethnic and multilingual by the producing company as well as in the marketing process, the production aims to surpass the mere examination of an isolated local conflict and makes the point that both theatre-making and theatre-going are practices that intersect with narratives of cultural hybridization. I suggest that the approach to translation practiced in 20/20 is akin to the notion of cultural translation common in post-colonial studies. Translation in this case is not merely about interlingual transfer (although this element is crucial); it is "not an interchange between discrete wholes, but a process of mixing and mutual contamination" (Sturge, 2011, p. 69). Homi Bhabha's (1994) words are also directly applicable here: translation is "the performative nature of cultural communication" (p. 228), and the resulting "hybridity" (p. 5) in language and cultural identity means that culture is equally "transnational and translational" (p. 5). In this way, I intend to show that in 20/20 languages complement rather than succeed one another, and, in fact, for most protagonists, they tend to be found overlaid and not substituted.

\section{Contextual background}

For those familiar with European history, Transylvania - where the play is set - emerges as an archetypal locus for a debate on the subject of belonging. Today it marks the Easternmost frontier of the European Union as part of Romania, prior to which it belonged to the AustroHungarian Monarchy, the Habsburg Empire, the Kingdom of Hungary, was under Ottoman rule and enjoyed relative independence as a selfgoverning principality. Its borders may have been moulded in the course of this millennial history, but its population, though fluctuating, has maintained its diversity in terms of ethnicity and religious orientation. 
Not even the communist rule managed to introduce full levelling in this sense, although the over four decade-long stifling of any individual or communal specificity led to an instant resurgence of identity claims after the fall of the communist dictatorship. Rising nationalism was one of these. However, unlike the former Yugoslavia where this type of conflict led to Civil War and territorial restructuring, in Transylvania it was strongly focalized and was conducted independent of territorial revision. The key debate during the last two decades since the fall of the communist regime in December 1989 has been over the right to utilize the Hungarian language more widely in public life, especially in education, and more recently, over regional self-determination within the current borders of Romania.

The events of March 1990 took public opinion by surprise. Not only did they occur within less than three months from the demise of Romania's communist dictator but they took place in a city known for its tolerance and laid-back atmosphere. Historically, the city has been emblematic for successful ethnic coexistence, and until the mid-twentieth century it was not only a bilingual but also trilingual place, a fact enshrined in its multiple names: 'Tîrgu Mureş' (also spelt Târgu Mureş) in Romanian, 'Marosvásárhely' in Hungarian and 'Neumarkt am Mieresch' in German. To this date there has not been a complete account of what exactly happened, apart from the fact that members of Romanian and Hungarian ethnic groups lashed out at one another, killing a total of five individuals and injuring around 300, including the award-winning playwright András Sütő. The memory of March 1990 has entered public consciousness as 'Black March' - Hungarians preferring the term 'pogrom', while Romanians 'ethnic violence' - and the events have become synonymous with the outburst of ultraviolent nationalism, ethnic prejudice and division. Following these events, the future of the nascent Romanian democracy seemed to be at stake, and so was the peaceful coexistence of ethnic communities - despite centuries of having shared the same geographical space. As it happens, calm was relatively swiftly restored, although it is difficult to ascertain whether this was a result of improved ethnic relations or merely a sign of resignation and acceptance of a new status quo. The fact remains (as confirmed by the 2011 census), that migration from the area increased significantly following the events, and families who would have never contemplated leaving during the communist period did now take the decision to relocate.

\section{On memory, fiction and documentation}

This lack of publicly available explanation to the events frames 20/20, which offers itself as a beginning of sorts in this sense. Aware that the events of March 1990 are still considered a major taboo, playwright and director Gianina Cărbunariu downplays any association with courage and 
argues instead for a need for "normalization" (quoted in Tompa, 2009, para. 15). Cărbunariu claims in her director's notes published in the programme accompanying the production that the "contradictory stories preserving the truth of these events have not been openly discussed before, yet they seem to define the atmosphere of the town and the relationship between Romanians and Hungarians even 20 years after the event" (Cărbunariu, 2012, p. 2). Adamant to avoid taking sides she contends that $20 / 20$ is the only account that explores both sides of this ethnic confrontation, and indeed the piece deploys a concerted effort to explore as many aspects as possible and conveys the point of view of ordinary Romanians and Hungarians, as well as visiting foreigners with their outsider perspective. Though directed by the Romanian Cărbunariu, the piece is the joint creative effort of the Hungarian Yorick Studio and the Romanian dramAcum company, and involves the participation in equal numbers of Romanian (Gabriel Iacoban, Paula Gherghe, Mădălina Ghiţescu, Rolando Matsongos, Cristina Toma) and Hungarian actors (Aba Sebestyén, Barna Bányai Kelemen, Katalin Berekméri, Klára Tompa, András Korpos). On the whole, the creative team would have been too young to recall the events themselves, therefore they conducted their own research by consulting documentary footage and wide-ranging (often contradictory) press coverage from the period. They also interviewed participants on both sides of the conflict. The programme notes claim that the production is "based on personal stories and interviews with the citizens of Tîrgu Mures, who either directly participated in the events or whose lives were influenced by them" (Cărbunariu, 2012, p. 2).

As a result, 20/20 comes across as a genuinely shared platform which sheds light on a controversial aspect of recent history, presumably prompted by the disappointment of not having found out anything worthwhile about this conflict in the two decades that have since lapsed. Thus, the title does not refer only to the Romanian-Hungarian clashes of March 1990 and the twenty years that have passed since then, but also to the ophthalmological terminology for a healthy sharpness of vision. Experimenting with the boundaries of theatre making in order to achieve this aim, the production explores site-specificity and routinely interweaves Hungarian and Romanian (alongside English and snippets of French) in a carefully choreographed effort to explore the conflict as fully as possible. In this way the piece makes the groundbreaking political point of situating all languages as equally valid, and positions all vantage points as comparably sound. The validity of this potentially controversial platform of shared contribution and responsibility was enhanced by the reception of the piece in both Romania and Hungary (it received several awards in both), ${ }^{1}$ and by its international circulation. The London premiere of 20/20, for instance, was presented in 2012 by the London International Festival of Theatre (LIFT) and the Romanian Cultural Institute, with support from the Balassi Institute (formerly known as the 
Hungarian Cultural Centre); it is on this occasion that I witnessed the production.

Despite being subsequently embraced as a flagship for intercultural cooperation, the production was not an instant hit. It premiered on 14 October 2009, and was written for a very specific audience - of Tîrgu Mureş/Marosvásárhely, a provincial city of around 125,000 inhabitants which, although it has its own drama school and important theatres, is not situated at geographical crossroads. Presented initially away from the metropolitan theatre scene of Bucharest, Romania's capital, 20/20 was not immediately picked up by theatre critics who only started paying attention to it after it had obtained a few awards at festivals. This reaction is fairly typical regarding theatre work produced by independent companies in Romania (such as Yorick and dramAcum), though somewhat surprising considering that director Gianina Cărbunariu is known as an enfant terrible of contemporary Romanian theatre, who has developed a strong international profile as a playwright and director and who never shies away from controversy. She has, for instance, taken on the Romanian government by co-devising a play about a potentially imminent ecological crisis resulting from aggressive gold mining in the Western Carpathians (Roșia Montană - pe linie fizică si pe linie politică/Roşia Montană - on a Physical and on a Political Line, produced in collaboration with the Hungarian State Theatre in Cluj in 2010).

With 20/20, arguably, Cărbunariu and her team did not target any one organization or individual in particular, although they were fully aware of breaking taboos in terms of subject matter and what might be termed as accurate representation. Just by addressing the topic of the 1990 conflict, they shattered the two decade-long awkward silence, and by bringing in a group of non-resident Romanian actors they eliminated (or at least sidelined) the indigenous Romanian perspective. The piece draws on details from actual historical events, and the London International Festival of Theatre (LIFT) website promoting the production's tour in London highlights precisely this aspect for British audiences familiar with the documentary genre:

$20 / 20$ is a piece of documentary theatre about the dramatic and traumatic events of March 1990 in Tîrgu Mureş, a bilingual city in Romania. News and information about the conflict was suppressed, and much of the detail now only exists in the memories of its protagonists. (LIFT 2012 website, para. 1)

Linking memory and dramatic representation signals the potential affiliation of this piece to the British tradition of theatre inspired by real life, which can of course constitute a very helpful endorsement for any company or playwright hoping to make their name in an international arena. Indeed, Cărbunariu talks about the dramAcum principle of getting to the bottom of events by carrying out interviews with real people about 
real events, rather than simply directing a pre-existing text. For Cărbunariu, "a theatre director's job commences at the moment of conceiving a project and continues with the documentation process" (quoted in Boicea, 2011, para. 3, my translation). She insists though that she does not make pure documentary theatre as such. She does use the method of documentation (alongside other methods); however, no interview or actual situation ends up being fully reproduced in the finished production:

Together with the actors, visual artist Maria Drăghici and dramaturg Kinga Boros we conducted around sixty interviews with various respondents; then we analyzed the material, improvised with the actors, I wrote a script and created a work of fiction (quoted in Ionescu, 2010, para. 5, my translation).

Consequently, in Romania the play was generally labelled as 'docufiction', critics insisting on the plausibility of events depicted in the piece and its "illusion of the real" (Fazakas, 2010, para. 7, my translation).

The programme notes categorize the production as multi-ethnic and multilingual, aiming to investigate "expressions of violent nationalism, prejudice, distrust and alienation” (Cărbunariu, 2012, p. 2), and stating that "these same feelings that plagued post-Communist Romania still lace many of the global conflicts today" (Cărbunariu, 2012, p. 2). The LIFT 2012 website dwells on the director's belief "in the importance of excavating these memories to understand how quickly ethnic tensions can once again rise up on the edges of Europe" (para. 2). ${ }^{2}$ This is precisely the reason why forging collaborations between people from different backgrounds and cultural climates is so important. Sharing the stage with speakers of other languages can help traverse national boundaries and challenge essentialist notions of national identity. For Cărbunariu, the topic of the 1990 interethnic conflict can help illuminate many subsequent events, which is why the production is made from the present perspective looking back on the past, rather than reconstituting events as if they were to take place in the here and now. In addition to the memories of interviewees, the company also integrated some of their own associations to the events. At times, performers use their own names and integrate objects with a personal significance. Actress Klára Tompa shares a tape she made at the age of sixteen, in which we can hear her telephone conversation with her then boyfriend who emigrated to Israel. According to Andrea György (2012, p. 5), this indirect reference to the Israeli-Palestinian conflict frames the issues of 20/20 in a broader context, and suggests that inter-ethnic tension is a global phenomenon. On tape, the young immigrant confesses that he is unable to associate killing Palestinians with a sense of duty or honour. In his case, inter-ethnic tension leads to an inner personal dilemma, while the play's onstage protagonists defy segregation on an ethnic basis and argue for the 
importance of dialogue to come to terms with the past and achieve reconciliation.

At stake, in the case of $20 / 20$, is clearly the present, alongside Romania's progress over the two decades since the events the play depicts. Instead of historical reconstitution, the production charts the ways in which people preserved in their memories some of the key political moments of the 1990s; in this sense the production is about memory first and foremost. Thus a re-evaluation of sorts is instantly embedded in the process: performers and audiences are fully aware of "the possibility of omissions and/or connections with later events" (Cărbunariu quoted in Ionescu, 2010, para. 7, my translation):

We started with the idea that it is pointless to search for absolute truth in relation to this event. I think that the illusion of an absolute truth has proved to be rather dangerous over the course of history. What we tried to find instead were as many points of view as possible, of those directly and partially involved, and even of those who were not involved at all. [...] Yet we were aware all the time that we were dealing with remembrance, and memory changes, edits and blurs things, exaggerates and minimizes certain aspects, while other aspects end up being seen through the perspective of what happened in the subsequent twenty year period. We were mainly interested in human details, snippets of daily life and people's relationships with those in their immediate environment. (Cărbunariu quoted in Blaga, 2010, para. 3, my translation)

This connection with the future is further emphasized by plans regarding the production's prospective run in the city for which it was written and whose history it documents. The company hopes to obtain funding to be able to show the production free of charge to a youth audience, possibly in schools, and to invite students and their teachers to a dialogue on topics arising from the piece. Cărbunariu is motivated by a search for topics that "open up a dialogue with a much larger audience than the regular theatregoing public" (quoted in Blaga, 2010, para. 1, my translation), and she perceives success in having achieved such a dialogue both during and after a show. Cărbunariu herself started writing and directing while at university and, together with a few fellow students, she founded in 2002 a new playwriting platform, dramAcum (meaning theatreNow), which later developed into the current cultural association. This initiative has since consolidated itself into the most prominent forum for emerging voices in Romanian theatre - both in terms of showcasing new writing and translations from lesser known languages and dramatic traditions. 


\section{Staging multilingualism}

Viewed in the context of Romanian theatre, the production puts forward a groundbreaking intermingling of multiple languages. According to Grutman (2011), “in literary poetics, 'multilingualism' stands for the use of two or more languages within the same text" (p. 183) and texts can either "give equal prominence to those languages or merely add a liberal sprinkling of foreign tongues to a dominant language clearly identified as the central axis" (p. 183). 20/20 brings together three languages on equal footing, seamlessly switching from one to another in the course of the production, and often placing one and the same actor in a position to swiftly move between them. On stage most performers would predominantly speak their mother tongue - denoting membership of a specific ethnic group, but also, in some cases, each other's language indicating the need and ability to communicate in an ethnically diverse area. English, as the language of international communication, is also spoken by several performers, either when embodying foreigners or as locals engaging with visitors. A fourth language, French is also briefly introduced to flag up a potentially controversial parallel: the situation of bilingualism in Quebec.

Cărbunariu stresses her intention to surpass the binary opposition between Hungarian and Romanian in the production. To this end, a Hungarian actor (Aba Sebestyén) is cast as a Romanian character attempting to convey a "Romanian perspective" (Cărbunariu quoted in Tompa, 2009, para. 10). She also claims that casting non-Transylvanian Romanian actors was a carefully considered decision: on the one hand, she wanted to work with her regular company, dramAcum, but, on the other, to avoid potential prejudice and allow more space for an outsider perspective that is not altogether foreign. This decision automatically led to most of the Romanian actors not being able to speak Hungarian; however, it may have been difficult to find enough Hungarian speakers even in a Transylvania-based Romanian company. The one Romanian actress who does speak Hungarian (Cristina Toma, a native of Tîrgu Mureş) speaks the language in several scenes. She also speaks English and French in her other scenes, thus emerging as the only performer who covers the full linguistic spectrum and juxtaposes local languages to the ones of international circulation. This aspect connects to personal details in the actress's life: she returned to Tîrgu Mureş after working in Canada for a very long time, and the scene where her character writes a letter - in Romanian and Hungarian (the languages of her parents) alongside English and French (the languages spoken in Montreal) - to the family left behind in Tîrgu Mureş, is of strong autobiographical resonance.

Thus, translation in $20 / 20$ is not merely a movement from source to target but is situated in the "third space, where conflicts arising from cultural difference and the different social discourses involved in those conflicts are negotiated" (Wolf, 2002, p. 190). Cultural translation in this 
interpretation of the term "transcends a purely linguistic horizon and becomes a cultural and political phenomenon" (Buden, 2006, para. 14). Crucially, 20/20 succeeds in avoiding the pitfalls frequently associated with cultural translation: threats of monolingualism and planetary English as mapped out by Trivedi (2005). Despite a concerted effort to integrate English (as a pathway towards international appeal and accessibility) the production steers clear from adapting the dramatic situation to the dominant idiom of western capitalism. The production makes every effort not to undervalue plurilingual cultural diversity, including actual details of linguistic difference and interlingual exchange. Thus, 20/20 not only refrains from undermining otherness but successfully contributes to reinstating the key role of translation in all its implications to the core of interdisciplinary discussions on cultural diversity.

Translation in 20/20 operates as a "transaction not between two languages, or a somewhat mechanical sounding act of linguistic 'substitution' [...], but rather a more complex negotiation between two cultures" (Trivedi, 2005, p. 3). In this case, the "unit of translation is no longer a word or a sentence or a paragraph or a page or even a text, but indeed the whole language and culture" in which that text is constituted (Trivedi, 2005, p. 3). On stage it is the ongoing provision of interlinguistic surtitling that draws attention to the regular switches between cultures and makes the different languages more salient for audiences potentially unfamiliar with a particular language used in the piece. This surtitling is integrated as an essential component of 20/20 and, in fact, it becomes the most pervasive form of translation in it: being present from beginning to end. In its turn, surtitling operates on multiple levels as interventions are translated between Romanian and Hungarian, but also into English. At any one time three languages are embedded simultaneously into the fabric of the performance.

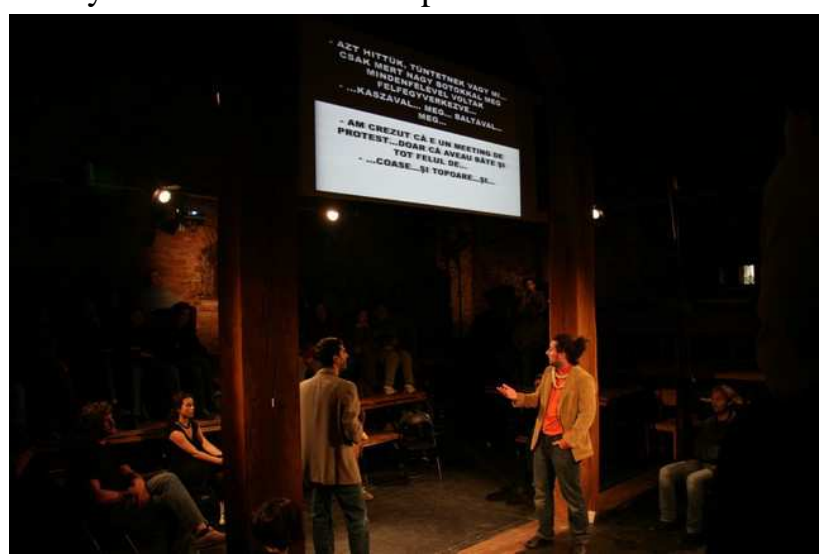

Figure 1: Interplay between languages in 20/20: spoken English dialogue surtitled in Romanian and Hungarian. 
In the situations where the performers embody foreign visitors and speak English, the dialogue is surtitled in Romanian and Hungarian, as in the illustration above:

Spoken English dialogue: "We thought this was a demonstration or something...except that they were armed with large sticks and all sorts of scythes... and axes..."

Romanian surtitling: "Am crezut că e un meeting de protest...doar că aveau bâte şi tot felul de ...coase...şi topoare..."

Hungarian surtitling: "Azt hittük tüntetnek vagy mi...csak mert nagy botokkal meg mindenfélével voltak felfegyverkezve...kaszával meg baltával...meg...”

Overall, great care was taken to make sure the three versions correspond in content, style and register. In this way, multilingualism on stage remains multilingualism in translation, as all interventions are offered an equal chance of being accessible. The ongoing presence of surtitling in two languages in 20/20 also means that the production does not assume a target audience of a particular ethnicity or linguistic prowess: it may be a polyglot public indulging in a rare polyglot show, but it may equally be various types of monolingual audiences encountered on national and international tours. Thus, the example of 20/20 confirms Doris BachmanMedick's (2006) contention that the idea and practice of cultural translation can "act as an anti-essentialist and anti-holistic metaphor that aims to uncover counter-discourses, discursive forms and resistant actions within a culture, heterogeneous discursive spaces within a society" (p. 37) and enable "a dynamic concept of culture as a practice of negotiating cultural differences, and of cultural overlap, syncretism and creolization" (p. 37.)

The literary tradition of linguistic minorities, on the whole, tends to demonstrate an openness towards linguistic diversity, and having Romanian and Hungarian alongside English and French in 20/20 simply references the increasing coexistence of these languages in day-to-day experience. In many cases, opting for a particular language at a given time is the result of "tactical" considerations (Grutman, 2011, p. 182). Thus, translation is often utilized for reasons including "dignity, civil rights or [even] timegaining" (Denison, 1978, p. 313) by "participants who do have a passive understanding of what was said in the other language but prefer to have it repeated in their own" (Grutman, 2011, p. 182, emphasis in the original). In other words, translation is not conducted with the aim to simply "re-encode basic semantic information for the benefit of a monolingual" target audience (Denison, 1978, p. 316), but has a defining social and political function.

In Transylvania, the politics of what language Hungarians should use with one another when non-speakers are also present is a longstanding delicate and contentious matter. Switching between languages 
and/or offering simultaneous interpreting is a standard practice, which the piece faithfully renders; however, the production also signals a new direction: that of celebrating interpersonal communication as a result of overcoming language difference. In the final scene of 20/20 adolescent girls research the internet to find out about the events of 1990s, and instinctively opt for English as a medium. This can of course be problematic in terms of information content, but the point Cărbunariu is making here is that, finally, Hungarians do have a choice regarding both the degree of embracing the official language (Romanian) and their loyalty to their native language, which they have been historically encouraged to preserve. Four languages - uttered by ten actors - coexist seamlessly in the course of this production, yet hardly ever are the speakers of these languages presented in a conflictual situation. The piece does not feature negative characters or obvious villains, despite the constant talk of conflict and tension. Refraining from the representation of violence on stage is, on the whole, a merit of the production, although Cărbunariu's political decision to sit on the fence with regard to causes of the conflict can be perceived as a problematic issue, especially since she blamed the media for a similar lack of clarity.

The only scene that presents a conflict between Romanians and Hungarians is anchored in a birthday party situation (that of the Hungarian Sárika) where invited and uninvited guests clash. Oscillating between burlesque and tragicomedy, the scene openly addresses Romanian fears of losing Transylvania to Hungary, leaving audiences flabbergasted by the audacity of tackling such a taboo topic not encountered before onstage. This central scene brings together most performers, and they are given the opportunity to create a tableau of gross ethnic, cultural and social stereotypes, e.g. Romanians are generally friendlier and Hungarians better educated and more sophisticated, that Hungarians listen to jazz and recite poetry and Romanians prefer low culture epitomized by cheesy music. The gathering includes individuals that have participated in the ethnic violence on opposite sides (a Hungarian couple, both doctors, saved from being lynched by two foreigners, and a Romanian working class type who supposedly beat up Hungarians), but this is only hinted at in passing, without any detailed clarification of facts.

The gathering is highly polarized, and everyone is instantly categorized in ethnic terms, apart from the half-Romanian, halfHungarian wife of the hostess's brother who, due to her bilingualism, has unhindered direct access to all private conversations. The Romanians, mostly born outside Transylvania, do not understand (enough) Hungarian, while the couple from Hungary, naturally do not speak Romanian. There is no common language shared by all participants, therefore the interventions in each individual's language and the relevant surtitling are accompanied by an element of simultaneous interpreting. This interpreting is conducted by another cast member participating in the 
scene, and unlike the surtitling that underpins the production as a whole, it is carried out sporadically and with varying degree of accuracy, as its aim is not so much to convey the exact meaning of words but to maintain a veneer of civility over repressed tensions about to escalate. The sole interpreter sufficiently trusted by both Hungarians and Romanians is the character with mixed origin and, although most Hungarians would be able to translate everyday speech from either Hungarian to Romanian or vice versa, their expertise is not required or indeed offered in this instance.

Apart from the half-Romanian and half-Hungarian actress playing a character who speaks both Hungarian and Romanian, in other scenes Hungarian actors also play Romanian characters. This separation of the ethnicity of the performer from the ethnicity of the character is a welcome departure from standard practices in both Romanian and Hungarian theatre, and argues for the validity of the point that language and ethnic identity are not defining factors. The (temporary) appropriation of another language and ethnic identity is portrayed as plausible and socially acceptable, and there are no attempts at disguising the performative nature of this operation. 20/20 shows Hungarian actors 'playing' Romanian and not 'being' Romanian or 'expecting to be perceived' as Romanian (they still preserve their accents, for instance), and in this sense it is immaterial whether audiences consider their take benign or aggressive. Addressing the changing relationship between two languages and two cultures, 20/20 emerges not only as a piece about memory and a particular moment in history, but about the representation and performability of ethnicity and of multilingualism on stage. In this sense, the title composed solely of numbers is an ironic triumph: these figures remain the same in both Romanian and Hungarian, as well as in English and French.

\section{Conclusions}

The article argues that translation and multilingualism are not mutually exclusive domains, and can exist side by side within a shared framework. It also claims that theatre and performance have a strong potential for revisiting and re-interpreting ideological narratives. Scrutinizing the contribution of multilingual theatre performances to the making of subjective and collective identities, the article investigates the coexistence of multiple languages within a single theatre production and claims that they play a role in articulating ideas and perceptions of belonging. In 20/20 all performers are associated with multiple languages and are involved in some form of translation, either by having their words instantly displayed via surtitling, and hence being translated by others, or by expressing themselves in at least another language in addition to their mother tongue, and thus, 'translating' themselves. The article shows that, irrespective of the form of translation utilized, the production endeavours 
to maintain a similar content, register and style throughout the various language versions provided. Inter-linguistic translation in 20/20, therefore, is a reliable tool for re-encoding key semantic information; however, its main purpose is to situate interventions in various language on an equal par. To put it differently, in addition to interlingual transfer, translation in this instance operates to make sure that none of the Hungarian, Romanian or English versions are absent or excluded, and thus the production makes a plea for an ideal status quo in terms of linguistic coexistence.

Crucially though, 20/20 refrains from adapting the dramatic situation to the dominant idiom of western capitalism. The highly visible presence of English in 20/20 could be interpreted as an attempt on behalf of speakers of different languages with relatively low circulation (such as Hungarian or Romanian) to translate themselves into the language expected to reach the widest audience (i.e. English and, to a lesser extent, French). This attempt is characteristic of "centripetal forms of globalization" (Pieterse, 1995, pp. 45-67), implying an understanding of globalization as a form of homogenization and, ultimately, westernization. 20/20, however, constitutes an exemplar of the "centrifugal form, suggesting globalization as resulting in interdependence, interpenetration, hybridity, syncretism, creolization and crossover" (Cronin, 2011, p. 128). In the latter understanding of translation, speakers of Hungarian and Romanian as represented in 20/20 are guaranteed the maintenance of their full sovereignty, being able to participate in civic life in a language of their own choosing. In this way, they not only preserve their linguistic autonomy in relation to the rise of English, but also in relation to each other, continuing to negotiate a mutually acceptable terrain for the safeguarding of their respective linguistic traditions.

Thus, the production succeeds in transforming the examination of an isolated local conflict into a universally valid parable, as the multilingual cast led by artistic director Gianina Cărbunariu succeed to steer clear of essentializing languages and identities. Through the separation of the performer's ethnicity from that of the character's, for instance, the representation of belonging or not belonging is tied in with questions of agency and performativity, and the right of individuals to affirm as well as interrogate their hereditary links to a community.

\section{References}

Bahmann-Medick, D. (2006). Meanings of translation in cultural anthropology. In T. Hermans (Ed.) Translating others, vol. 1 (pp. 33-42.) Manchester: St Jerome.

Bhabha, H. (1994). The location of culture. London: Routledge. 
Blaga, L. (2010). Interviu cu Gianina Cărbunariu/Interview with Gianina Cărbunariu. Cultura.In Mures.Ro. 5 July. Retrieved from http://cultura.inmures.ro/ proiecte/detalii-proiect/detalii-proiect/article/2868/1751.html.

Boicea, D. (2011). Gianina Cărbunariu: "Teatrul românesc are nevoie de un shut down şi de un restart"/Gianina Cărbunariu: "Romanian theatre needs a shutdown and a restart". Adevărul. 4 January. Retrieved from http://adevarul.ro/cultura/arte/gianina-carbunariu-teatrul-romanesc-nevoieshut-down-restart-1_50acdd937c42d5a6638ad3ac/index.html.

Buden, B. (2006). Cultural translation: Why is it important and where to start with it? Retrieved from http://eipcp.net/transversal/0606/buden/en.

Buden, B., Nowotny, S., Simon, S., Bery, A., \& Cronin, M. (2009). Cultural translation: An introduction to the problem, and responses. Translation Studies, 2(2), 196-219.

Cronin, M. (2011). Globalization. In M. Baker \& G. Saldanha (Eds.), Routledge encyclopaedia of translation studies (2nd ed., pp. 126-129). London: Routledge.

Cărbunariu, G. (2012). Director's notes. 20/20 Programme. London International Festival of Theatre (LIFT). London: Platform Theatre, 4-6 July.

Denison, N. (1978). On plurilingualism and translation. In L. Grähs, G. Korlén, \& B. Malmberg (Eds.), Theory and practice of translation (pp. 313-319). Bern: Peter Lang.

Fazakas, M. (2010). Douăzeci/húsz - 20/20. Observator cultural. February. Retrieved from http://agenda.liternet.ro/articol/10740/Matyas-Fazakas/Douazecihusz2020.html.

György, A. (2012). Erős várunk nékünk a szinház: Gianina Cărbunariu 20/20 címü rendezéséről/A mighty fortress is our theatre: On Gianina Cărbunariu's production of 20/20. Játéktér. December. Retrieved from http://www.jatekter.ro/?p=890.

Grutman, R. (2011). Multilingualism. In M. Baker \& G. Saldanha (Eds.), Routledge encyclopaedia of translation studies (2nd ed., pp. 182-185). London: Routledge.

Ionescu, D. (2010). Gianina Cărbunariu: "Fac teatru pentru cei care nu cred în teatru"/Gianina Cărbunariu: "I make theatre for those who don't believe in theatre". Yorick, 53. 29 November. Retrieved from http://yorick.ro/gianinacarbunariu-fac-teatru-pentru-cei-care-nu-cred-in-teatru/.

London International Festival of Theatre (LIFT, 2012) website. Retrieved from http://www.liftfestival.com/content/14299/archive/2012/lift_2012/2020/202.

Pieterse, J. N. (1995). Globalization as hybridization. In M. Featherstone (Ed.), Global modernities (pp. 45-67.) London: Sage.

Sturge, K. (2011). Cultural translation. In M. Baker \& G. Saldanha (Eds.), Routledge encyclopaedia of translation studies (2nd ed., pp. 67-70). London: Routledge.

Tompa, A. (2009). Cu rucsacul acesta de prejudecăţi în spate - 20/20: un interviu cu Gianina Cărbunariu/Loaded with prejudice - 20/20: an interview with Gianina Cărbunariu. Observator cultural, December. Retrieved from http://agenda.liternet.ro/articol/10469/Andrea-Tompa-Gianina-Carbunariu/Curucsacul-de-prejudecati-in-spate-2020.html. 
Trivedi, H. (2005). Translating culture vs. cultural translation. 91st Meridian, May. Retrieved from http://iwp.uiowa.edu/91st/vol4-num1/translating-culture-vscultural-translation.

Wolf, M. (2002). Culture as translation - and beyond: Ethnographic models of representation in translation studies. In T. Hermans (Ed.) Crosscultural transgressions: Research models in translation studies. (pp. 180-192.) Manchester: St Jerome.

1 The production received the following nominations and awards: nominated for the Best Independent Performance of the Year Award by the International Theatre Critics' Association from Hungary (2010); the Special Award of the Jury at the National Theatre Festival in Pécs (POSZT) and the Rivalda Award from the Thália Theatre in Budapest, Hungary (2010); the Award of the International Theatre Critics' Association from Romania (2010); the award offered by the Szülöföld [Homeland] Foundation at the Festival of Hungarian Theatres in Kisvárda (2010).

2 Retrieved from http://www.liftfestival.com/content/14299/archive/2012/lift_2012/ 2020/2020. 